\title{
The German skill formation model in transition: from dual system of VET to higher education?
}

\author{
Martin Baethge, Andrä Wolter
}

Published online: 28 July 2015

(C) Institut für Arbeitsmarkt- und Berufsforschung 2015

\begin{abstract}
The German system of skill formation, in particular the dual system of vocational education and training (VET), is considered in the political economic debate to be a pillar of the German model, mainly for two reasons: On the one hand, training of skilled workers was supported by the specific path of development of diversified quality production from its beginning. On the other hand, the dual VET system represents one of the most important fields for the German corporatist governance system.

The article develops the following ideas: the conditions of the German VET system fundamentally changed during the second half of the twentieth century: Cognitive preconditions for VET continuously increased, and since the mid1960s educational reform and expansion in Germany (old Länder) gradually resulted in increasing higher levels of education and in a differentiation of the educational landscape as well as in a shift in young peoples' educational careers towards higher education.

The driving forces behind these developments will be analysed and discussed with respect to their impact on the relation between the dual VET system and higher education. The argumentation results in the following conclusion: Firstly, the broad trend toward upskilling the German labour force will continue and the integration of low-qualified youth into VET and the labour market will become more precarious than in the past. Secondly, corporatist governance of the dual VET-System will come more and more under pressure and become less important in the German educational system as a whole.
\end{abstract}

M. Baethge $(\triangle) \cdot$ A. Wolter

Soziologisches Forschungsinstiut Göttingen,

Göttingen, Germany

e-mail: mbaethg@gwdg.de

\section{Das deutsche Ausbildungsmodell im Umbruch: zwischen dualem Berufsbildungssystem und Hochschulstudium}

Zusammenfassung Das deutsche Ausbildungssystem, insbesondere das duale System der Berufsausbildung, wird in der politischen Ökonomie aus wenigstens zwei Gründen als Grundpfeiler des deutschen Modells angesehen: Zum einen ist die Facharbeiterausbildung unauflöslich mit dem deutschen Industrialisierungspfad der diversifizierten Qualitätsproduktion verbunden, gleichsam als dessen qualifikatorisches Rückgrat. Zum anderen stellt das duale Berufsausbildungssystem eines der wichtigsten Felder des deutschen korporatistischen Steuerungssystems dar.

Der Artikel entwickelt folgende Argumente: Die Bedingungen des deutschen Berufsausbildungssystems haben sich in der zweiten Hälfte des 20. Jahrhunderts fundamental gewandelt: Die kognitiven Voraussetzungen für Berufsausbildung haben sich kontinuierlich erhöht. Seit der Bildungsreform Mitte der 1960er Jahre hat sich das durchschnittliche Bildungsniveau der Bevölkerung sukzessive erhöht, die Bildungslandschaft in Deutschland ausdifferenziert und haben sich die Bildungskarrieren immer weiter in Richtung Hochschulbildung verlagert.

Die hinter diesen Entwicklungen stehenden Kräfte werden analysiert und in ihrer Bedeutung für das Verhältnis zwischen dualer Berufsausbildung und Hochschulbildung diskutiert. Im Ergebnis kommt der Beitrag zu zwei zentralen Schlussfolgerungen: 1. Der breite Trend zur Qualifikationserhöhung (upskilling) in der deutschen Beschäftigungsstruktur wird sich fortsetzen, und die Arbeitsmarktintegration gering qualifizierter Jugendlichen wird deutlich prekärer als in der Vergangenheit. 2. Die korporatistische Governance des dualen Systems wird immer mehr unter Druck geraten und im Bildungssystem insgesamt an Gewicht verlieren. 


\section{Theoretical and empirical perspectives on skill formation in Germany}

The German system of skill formation, in particular the dual system of vocational education and training (VET), is considered in the political economic debate to be a pillar of the German model, mainly for two reasons: On the one hand, training of skilled workers was supported by the developmental strategy of diversified quality production since its inception. On the other hand the dual VET system represents one of the most important areas of corporatist governance in Germany.

The political economy of skill formation shows the specific impact of the dual system of VET on the production model and the development of the welfare state model in Germany (Soskice 1999; Culpepper and Finegold 1999; Streeck 1991; Thelen 2004). Recent research on the political economy of collective skill formation (Busemeyer and Trampusch 2012) follows this approach, building on previous research that emphasises the the link between VET and other political-economic institutions (Busemeyer and Trampusch p. 12), especially labour market institutions.

Due to its institutional approach, the political economy debate is geared to the level of regulation and thus neglects the empirical processes underlying ongoing changes in regulation. The focus is on the dual vocational education of skilled workers and the social partners associations as its political representatives (Busemeyer and Trampusch, p. 22). This explains why the skill formation system as a whole (including higher education and school-based training tracks) has received little attention in the political economy literature focusing on institutions. The same applies to higher education research although there have been some new approaches to link the higher education development more directly to the political economy debate (Graf 2009, 2010; Andres and Pechar 2013).

For more than a century the development of the general education system was more or less neglected in discussions on VET, for three reasons: First, the Gymnasium track traditionally led to higher education programmes at universities, not to VET programmes (only a few students entered dual programmes after leaving the Gymnasium). Second, the social background of students in VET and higher education varied and consequently there was little competition for educational qualifications. Third, until the second half of the twentieth century, educational programmes for craftsmen and skilled workers seemed to focus on basic cognitive skills (reading, mathematics) only, rather than the wider range of cognitive skills emphasized at universities and other types of schools for general education. This is reflected in the fact that up to now no school leaving certificate is required to enter dual VET programmes.
These conditions fundamentally changed during the second half of the twentieth century: Cognitive prerequisites for VET continuously increased and since the mid-1960s educational reform and expansion in Germany (old Länder) has gradually resulted in increasingly higher levels of education and in a differentiation of the educational landscape and young peoples' educational careers. In addition, when the dual VET system was dominant and higher education played only a minor role, both sectors co-existed without any problems. However, since the beginning of the twentyfirst century this situation has changed substantially.

For the first time in the German qualification system, the number of new entrants into university and the number of entrants into dual vocational education and training (VET) was just about the same in the past few years. Up to the beginning of this century the number of entrants into dual VET was nearly twice as high as the number of entrants into university studies (Fig. 1).

This quantitative shift in the relationship between the major educational sectors invigorated the discussion on the future of the German skill formation system as a whole: Will the system change towards higher education or will the traditional model of dual vocational education remain the backbone of German industry and the educational model for the majority of employees? A third option would be a new model of skill formation, integrating both systems into a new educational order.

The quantitative relationship between both sectors is demonstrated by the development in new entrants. Until the mid-1960s higher education was reserved for a small group of students, in particular from the middle classes. By that time, vocational education was the main pathway into qualified employment for the majority of young people (Fig. 1). Then, education reform and educational expansion created new dynamics: by the late 1960s entrants to universityand later to colleges of applied sciences (Fachhochschule) started to continuously increase, whereas entrants to VET, with some temporary upward and downward turns, continuously decreased. The preliminary end of this development was reached in 2011/2012 when there was an equal number of entrants in both sectors. ${ }^{1}$

The question of possible developments of the German skill formation system not only concerns employment and economic growth; it also has an impact on social structure and industrial relations. In Germany this question is currently being discussed mainly from three perspectives, which are the points of departure for this paper:

\footnotetext{
${ }^{1}$ Besides the dual system there is a full-time school-based VET sector which is attended by about one quarter of all apprentices. Traditionally this sector is not considered typical for the German model of VET in the political debate. That is why this article does not deal with schoolbased training.
} 
Fig. 1 Entrants to VET (dual system) and higher education 1950-2011. (Vocational schools: new entrants, until 1990 and from 2005 old Länder, 1991-2004 old Länder plus Ost Berlin, New entrants in higher education: until 2000 old Länder, from 2002 old Länder plus Ost-Berlin, Source: Federal Statistical Office)

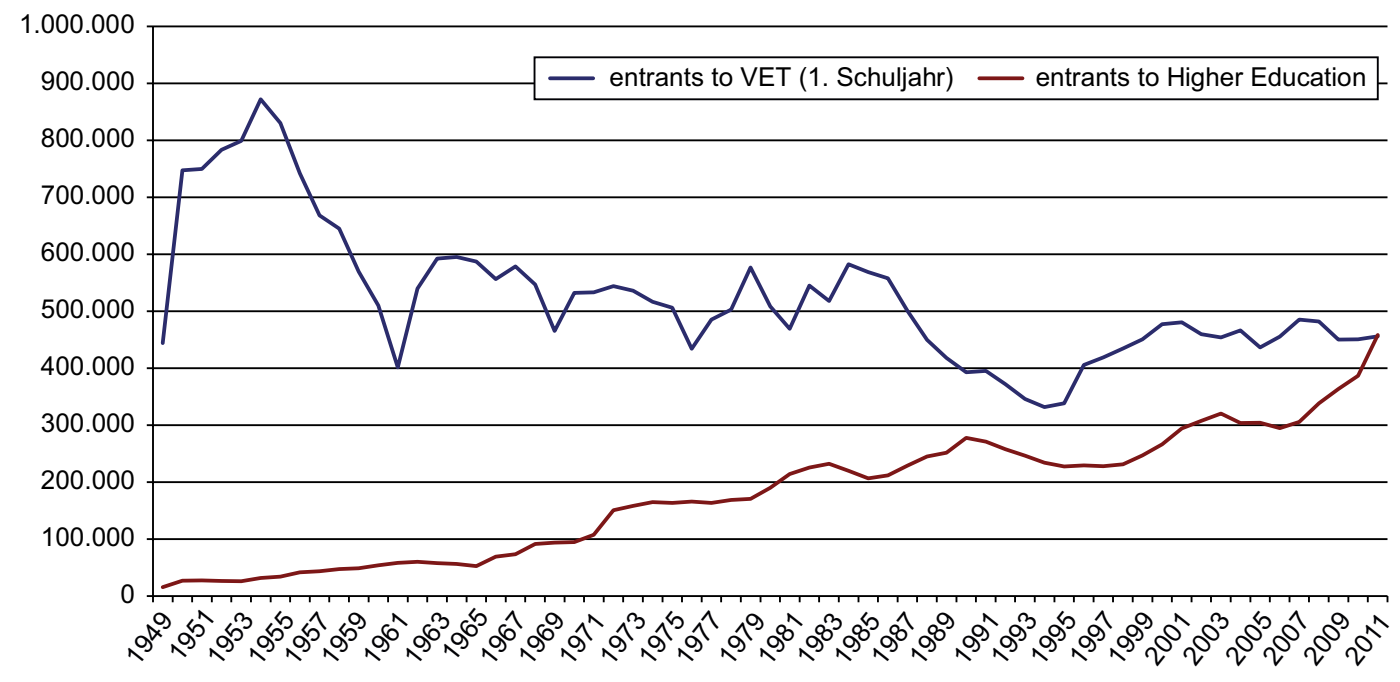

- First, there is the politically pragmatic point of view, mainly supported by the social partners, focussing on their domain of vocational education and training. Given the expansion of higher education, they are concerned about the future of the dual VET system. This refers to the attractiveness of dual vocational education compared to higher education with respect to the demographic decrease of school-leavers in the coming 2 decades and the reform of higher education within the Bologna process (Kuda et.al. 2012). It is not surprising that this question is mainly addressed by the social partners, in particular by the trade unions: their possibilities for recruiting new members and for participation in society are at risk. In the frame of reference of vocational training policy as well as higher education policy the steep increase in the number and proportion of first-year students has provoked a critical debate about this development under the topos of the accelerating academisation of the labour market and the employment system.

- A second perspective is based on the new institutionalism in social sciences. Here the German VET system represents an outstanding paradigm for the interaction between institutions in coordinated market economies because the German model is considered to be a "paradigmatic case of a distinctly successful and decidedly 'nonliberal' training regime"' (Thelen 2012, p. VI). Relating to the discussion on the transformation of the German model, this perspective is important and therefore will be discussed further.

- A third theoretical perspective, particularly widespread in higher education research, is based on the assumption that mass higher education is the appropriate qualification model for the emerging knowledge society. According to this approach one of the reasons for the shift from vocational training to higher education is a fundamental transformation in the patterns of knowledge production from experience-based knowledge to theoretical knowledge in different forms. Because of this, higher education institutions have become (besides other non-university research institutions) dynamic places for knowledge generation and dissemination, either in a discipline or in a more application oriented context (Gibbons et al. 1994; de Weert 1999; Brennan 2008; Välimaa and Hoffman 2008). So, the growing 'academisation' of skill formation mirrors the continuous enforcement of a particular type of knowledge in society in general as well as in the sector of work in particular. And this process is accompanied by some changes in class structures, especially by the emergence and extension of the social classes of higher- and lower-grade professionals (Erikson and Goldthorpe 1992, p. 38).

In view of the historical institutional separation of the main educational sectors (discussed in Sect. 2 below)-higher education and dual vocational education and trainingthe text will examine in more detail the how the relationship between the two sectors has changed in recent years (as already described in Sect. 1). Against the background of recent developments, we will then discuss the significance of the changes in vocational education and training and higher education with respect to the social structure and the labour market (Sect. 3). After that, we will scrutinise the factors and conditions determining these shifts. These will be analysed from two perspectives: the changing educational behavior and the changing structures in the labour market and employment (Sect. 4). Finally we will describe some new attempts at linking vocational and higher education (Sect. 5) before turning to the institutional side of these developments and discussing whether the new configuration of the relationship between vocational education and higher education indicates a fundamental transformation in the German system of skill formation (part 6). This includes 
new organizational arrangements between both sectors as well as new governance structures.

\section{The legacy of the past: the segmentation between vocational and higher education}

To understand the ongoing developments in the German system of skill formation, it is necessary to consider its historical development. The traditional German model of skill formation comprised two strictly separate sectors: the higher education (sub-)system and the system of dual vocational education and training. During the nineteenth and early twentieth centuries both systems formed their own institutional orders based on completely different construction principles (cp. stylised description in Table 1). The different institutional orders of both sectors were reflected in different educational paths leading to one of these (sub) systems and in the structures of employment and work associated with either vocational training or higher education. There has been a relatively clear distinction between professional activities requiring either an academic or a VET degree, with a limited area of intersection. Both systems have been subject to different financing structures, governance regimes and regulation procedures concerning the function and influence of the state, market mechanisms or collective stakeholders, such as social partners.

The different institutional orders in both higher education and VET restricted the permeability between the two. Access to higher education depended nearly exclusively on the formal study entitlement linked with the grammar school degree, the Abitur. Contrary to higher education there is no specific certificate of access to VET required by law.

VET institutions developed separately from general education and universities during the nineteenth and early twentieth centuries. This might be interpreted as a response to national education policy, which focused on the concept of general education explicitly avoiding the trades and emerging industries in the early nineteenth century. The concept was mainly pursued by the Gymnasium and universities (Baethge 2007; Wolter 1990), which correspondingly showed the greatest distance and explicit distinction from all forms of vocational education up to the last third of the nineteenth century.

Rooted in the tradition of crafts, the focus of VET was to ensure and develop the quantitative and qualitative demand for skilled workers. The preindustrial crafts educational system of the early twentieth century was adapted by industry (with the exception of guild membership and regulations). It was then modified and developed with industry-specific educational paths (Greinert 2007, 76 ff.). At this time, postsecondary part-time vocational schools were established as a counterpart to apprenticeship in firms, with the focus on general and theoretical vocational education. However, they were not linked to Gymnasium or universities.

Industrial enterprises and their representation of interests adapted crafts education and training for their own economic reasons - without external policy pressure. Since that time this craft-based VET system accompanied the German production model of "diversified quality production" (Abelshauser 2004, p. 42), as its backbone of qualification.

Table 1 Institutional orders of VET (dual system) and Higher Education

\begin{tabular}{|c|c|c|}
\hline $\begin{array}{l}\text { Distinctive criteria of skill formation } \\
\text { institutions }\end{array}$ & Higher education $^{\mathrm{a}}$ & Dual system of vocational education and training \\
\hline Guiding principle (main objectives) & Academic professionalism & $\begin{array}{l}\text { Vocational competence in firms and labour } \\
\text { markets }\end{array}$ \\
\hline Normative references for curricula & $\begin{array}{l}\text { Representative systematic knowledge in } \\
\text { academic disciplines }\end{array}$ & $\begin{array}{l}\text { Labour market and employment structure; eco- } \\
\text { nomic demand for qualifications }\end{array}$ \\
\hline Political governance & Länder governments & $\begin{array}{l}\text { Corporatist: (self-)governance by social partners } \\
\text { (chambers of trade, industry and commerce), } \\
\text { regulated by federal law }\end{array}$ \\
\hline Financing & Public by the Länder governments & Mainly by private enterprises \\
\hline Status of the learners & Students & Apprentices with employment contract \\
\hline Location/organisation of learning processes & $\begin{array}{l}\text { Universities; institutions independent from } \\
\text { workplaces }\end{array}$ & Firms; integrated in work processes \\
\hline Qualification of teaching personal & University degrees; $\mathrm{PhD}$ & $\begin{array}{l}\text { Semi-professional: master (craftsman) diploma; } \\
\text { journeyman diploma }\end{array}$ \\
\hline Conditions for access & Abitur; A-level degree (grammar school) ${ }^{\mathrm{b}}$ & Certificate of access not legally required \\
\hline $\begin{array}{l}\text { Areas of employment associated with type } \\
\text { of skill formation }\end{array}$ & $\begin{array}{l}\text { Academic professionals in public and private } \\
\text { administrations, research and leading } \\
\text { positions; liberal academic professions }\end{array}$ & Skilled work in production and service industries \\
\hline
\end{tabular}


From the firms' point of view, qualification supply was reasonably successful this way along with the migration of skilled workers from crafts to industry. When the chambers of industry and commerce ensured coordination and supervision of VET, demands for external policy control and participation by the trade unions could be rejected for reasons of high functionality - up to the Vocational Training Act of 1969. The Vocational Training Act of 1969 replaced the traditional corporatism with a modern version, integrating trade unions into the steering of VET, thus satisfying the German social model. The gap between VET and higher education did not change because the autonomy of vocational curricula and types of vocational education and steering were not questioned and perspectives for better permeability were not integrated.

From a historical point of view higher education has been strictly separated from vocational training since the beginning of the development of the German university in the late Middle Ages. This was partly due to the fact that individuals in academic fields and in non-academic occupations were allocated to different social orders, and partly due to the assignment to different employment fields. At first, academic education was exclusively linked with working in the church and in the court sector and-later on-in the state sector where the large majority of university graduates found employment. The slow process of opening up the private sector in the economy and the labour market for graduates with a higher education degree - including the sector of independent (self-employed) professions - did not develop until the middle of the nineteenth century, particularly during the period of industrialisation. But the pre-dominance of the public employment of graduates continued far into the twentieth century.

The typical path to the university was via school education and not via vocational training. Between 1780 and 1840 the transition from upper secondary school to university was bound to a formal school certificate, the Abitur. The formal study entitlement and the development of the actual study proficiency were considered to be the monopoly of the grammar school.

Hence, during the nineteenth century a particular institutional and normative order was established to regulate the route to universities, independently from vocational education. That is the main reason that institutions for vocational training have been under pressure to justify establishing a connecting point to higher education without the detour via evening grammar schools (or similar institutions), even up to the present day. This heritage of strict separation strongly shaped the development of access to higher education in the twentieth century, resulting in a very low degree of permeability between vocational training and higher education. Not until the 1970s was access to higher education opened up a little bit for applicants without an Abitur by the introduction of a second sector beside the universities, the Fachhochschulen, with its own access route via special vocational schools (e.g. the Fachoberschulen). This type of non-university institution - approximately one third of all students are enrolled in this sector-focuses on more vocationally oriented courses in engineering, business administration, social work and other applied sciences. In contrast, university courses and programs are rather discipline- and research-oriented, even in those cases when they refer to a particular profession (e.g. training of lawyers, doctors or teachers). For that reason the separation between vocational training and academic learning is not as strict in the nonuniversity sector as it is in the university sector, and this is reflected in the admission regulations.

\section{Skill formation development and social structure}

Parallel to the education reform, but not necessarily related to it, the VET system developed in a twofold way: on the one hand, the differentiation of vocational training sectors advanced; on the other hand, there was an increasing segmentation of vocational training occupations according to the level of previous education. This can be called an internal social stratification of the dual system due to the strongly class related education system in Germany (Maaz et al. 2010).

Based on statistical data, the differentiation of the VET system can only be reconstructed for the past 20 years. Based on the number of entrants, the dual system, with periodic upward and downward turns, has remained static since 1995 and has only recently declined. The school-based vocational system expanded slightly, but did not succeed in increasing the proportion of all VET entrants by more than $20 \%$ within the reference period. The transition system represents the critical institution of VET. Comparing the shifts between the three sectors over time shows that the transition system is highly dynamic. Until 2005 the transition system absorbed the demographically increasing demand for vocational training and subsequently the demographically decreasing demand. However, the transition system currently still absorbs more than a quarter of applicants for vocational education every year. The problem of the transition system is that it provides vocational preparation but no vocational qualifications (Fig. 2).

Due to the inability of the two main vocational sectors (dual VET system and full-time school-based vocational education) to provide the supply in accordance with the demand, about $40 \%$ of school-leavers were displaced in the transition system each year. Chances of successfully integrating young people without qualification into the labour market are limited, in particular for those from the lower classes. Accordingly, $18-20 \%$ of all $30-35$ year olds cur- 
Fig. 2 Entrants to the sectors of vocational education and training with qualifications and the transition system 2000-2013. (Source: Autorengruppe Bildungsberichterstattung 2014, p. 99.)

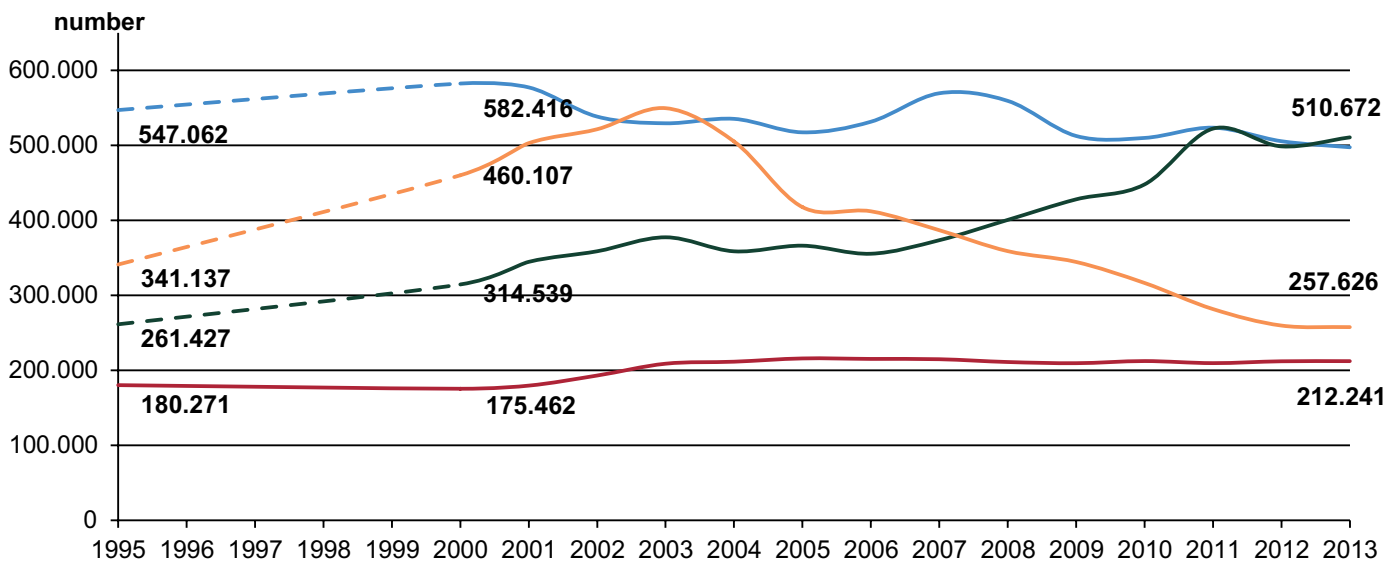

\begin{tabular}{ll}
\hline New entraints in VET & New entraints in school-based vocational education \\
New entraints in higher education & New entraints in the transition system \\
\hline
\end{tabular}

Table 2 Classification of occupations according to school leaving certificates $\left(\right.$ model $\left.^{\mathrm{a}}\right)$. (Source: Baethge and Wieck 2013, p. 84)

\begin{tabular}{ll}
\hline Upper segment & $>50 \%$ of new entrants with permission to enter higher education \\
\hline Upper middle segment & $>50 \%$ of new entrants with intermediate school-leaving certificate and $>75 \%$ with intermediate school-leaving \\
& certificate and in addition more than one quarter with Abitur \\
Lower middle segment & $>50 \%$ of new entrants with intermediate school-leaving certificate and $>75 \%$ with intermediate school-leaving \\
& certificate and in addition more than $25 \%$ with a secondary school leaving certificate (Hauptschule) \\
Lower segment & $>50 \%$ with secondary school leaving certificate (Hauptschule)
\end{tabular}

${ }^{\mathrm{a} B a s e d}$ on data from 2008

rently in the labour market are without vocational qualification (Autorengruppe Bildungsberichterstattung 2012, p. 43).

The inability of VET to provide training places implicitly undermined the legitimation of the VET system. Since no entrance qualification - at a formal level — was required to enter the dual VET system, in the past it was considered as a pathway to qualification and participation in society for children of the lower classes. Due to the development of VET during the past 20 years the implied assurance of social integration of the lower classes, including many migrants nowadays, is called into question. One important reason is the increasing social structuring of dual VET according to occupations and levels of general education. This might be considered to be a response by firms to higher qualification requirements and the increased supply of graduates with Abitur. The result is a social segmentation of vocational education and training.

The total number of new entrants into dual VET can be grouped hierarchically into segments according to their level of general education and occupations. Each segment is defined according to the predominant school leaving certificates: (Table 2)

Both upper segments include occupations almost exclusively reserved for young people with permission to enter higher education or an intermediate school-leaving certificate. This covers two-fifths of all new apprenticeship con- tracts in the dual system. With $62 \%$ of young adults holding a higher education access qualification, the upper segment ${ }^{2}$ can nearly be referred to as the Abitur segment. Young people with secondary school leaving certificate (Hauptschule) have almost no chance to enter this segment, representing only $3 \%$ of the new apprenticeship contracts. The second segment ${ }^{3}$, classified as "upper middle segment" shows a comparably high rate of school-leavers with an intermediate school-leaving certificate and in addition more than one quarter with Abitur. Also in this segment, only about one-seventh of young people with a secondary schoolleaving certificate (Hauptschule) are represented. Even in the third segment ${ }^{4}$, the "lower middle segment", the intermediate school-leaving certificate is dominant, whereas young adults with a secondary school-leaving certificate (Hauptschule) are represented only by one third. Only in the lower segment ${ }^{5}$ do young people with a secondary school

\footnotetext{
${ }^{2}$ This segment includes, for example, commercial occupations in financial services, new information technology and media designer occupations.

${ }^{3}$ Occupations such as clerks in public and private administration and some qualified industrial occupations such as electricians, industrial mechanics, laboratory assistants etc.

${ }^{4}$ This segment represents mostly occupations from industry, commerce and trade and less from administration.

${ }^{5}$ The segment collects most of the trade occupations (nutrition industry, building industry etc.)
} 
Fig. 3 Percentage of new apprenticeship contracts in 2010 according to occupational segments and the level of general education. (Source: Autorengruppe Bildungsberichterstattung 2012, p. 112, slightly modified by the authors)

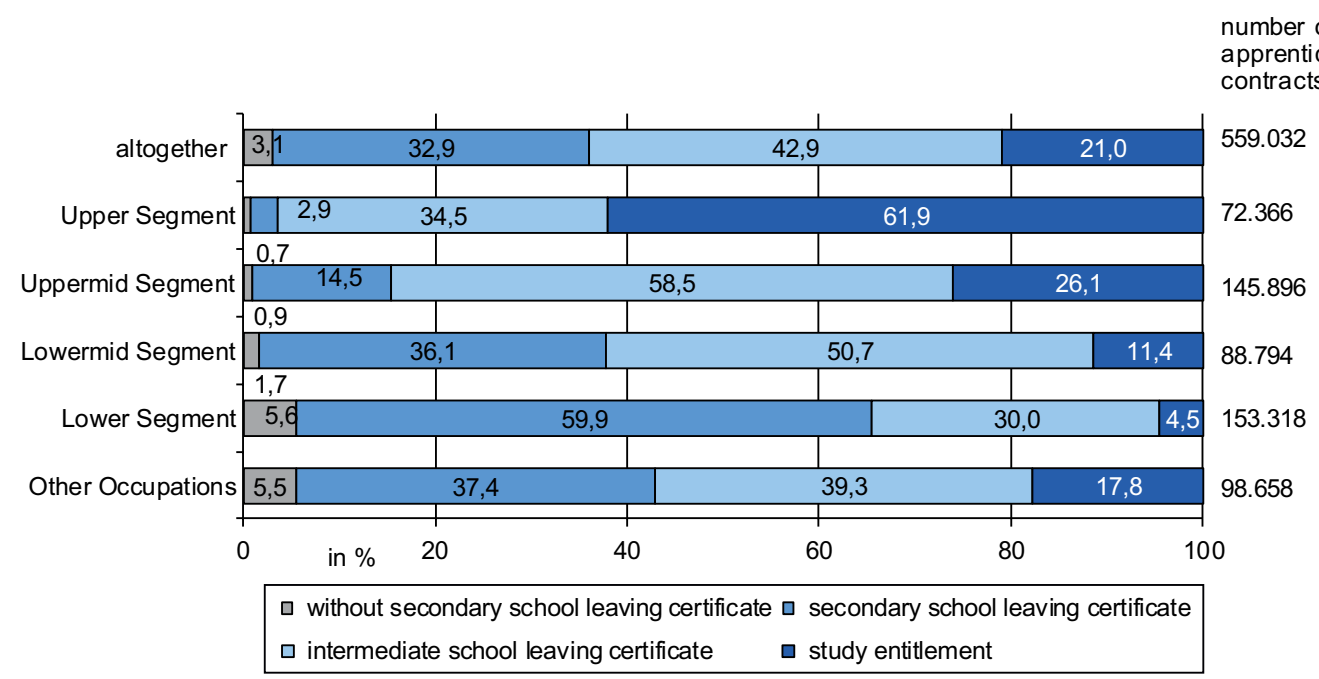

leaving certificate represent the largest group (two-thirds). In this segment, $30 \%$ have an intermediate school-leaving certificate and only $4.5 \%$ have permission to enter higher education. This Hauptschule segment represents about one quarter of all training occupations (see Fig. 3).

Compared to training market booms, the educational structure of occupational segments has been relatively resistant since 1995 (Baethge and Wieck 2013, 143 et seqq.), in particular in the upper segments. For the education, training and labour markets the social structuring implies that young people with only a secondary school-leaving certificate (Hauptschule) — and very often migration background - can choose between very few occupations only. If the tendency towards higher education continues and dual vocational education and training become even less attractive for young adults with permission to enter higher education, it is likely that recruiting shortages in companies will emerge very soon, not only in the upper segments. Furthermore, social inequality within the dual system will tend to become stabilised for a long time.

\section{How to explain the development of VET and higher education?}

In the following section we will look into the factors and conditions determining the shifts between VET and higher education. This will be analysed from two perspectives: firstly from changing educational behavior (4.1) and secondly from the changing structures in the labour market and employment (4.2). Both perspectives are related to each other. Though institutionally separated, both the education system and the labour market and employment system are affected by the same larger trends in society and the economy: in particular by the all-embracing tendency towards digitalized work, the increasing globalisation of production chains and labour markets and the tendency towards new (more demanding) lifestyles.

\subsection{Changes in educational participation}

The most important factors that have caused expanding social demand for higher education and decreasing participation in VET (Fig. 1) are the fundamental changes in educational decisions and behaviour manifested in the preference for different school types. There has been a dramatic change in the educational decisions determining the allocation of pupils across the different school types within the secondary school system. In the early 1950s the share of pupils transferring from the primary to the lower secondary school (Volksschule, since 1965 Hauptschule) amounted to more than $75 \%$ nationwide; this proportion decreased continuously to less than $12 \%$ in 2012 (Cortina et al. 2008, p. 76; Autorengruppe Bildungsberichterstattung 2014, p. 254).

On the other hand, the participation rate in the grammar school track (at grade 5 or 7) leading to the entitlement necessary to access higher education has expanded in the same period from $15 \%$ to more than $40 \%$ (Cortina et al. 2008). During this period institutional permeability within the school system has increased to a limited extent, e. g. by the establishment of new school types and by opening up some further transition pathways for accessing the upper level of the grammar school or obtaining a higher education study entitlement. As a result of these partly structural, partly behavioral changes the proportion of students leaving the school system with an entitlement to study at university has risen steadily (Fig. 4) from less than $5 \%$ in the early 1950 s to currently approximately $50 \%$ of the age cohort. As a consequence, the potential demand for higher educa- 
Fig. 4 Proportion of school-leavers with a higher education study entitlement related to the age-cohort, 1950-2012. (Source: Statistisches Bundesamt, until 1992 only West-Germany, from 1992 all of Germany)

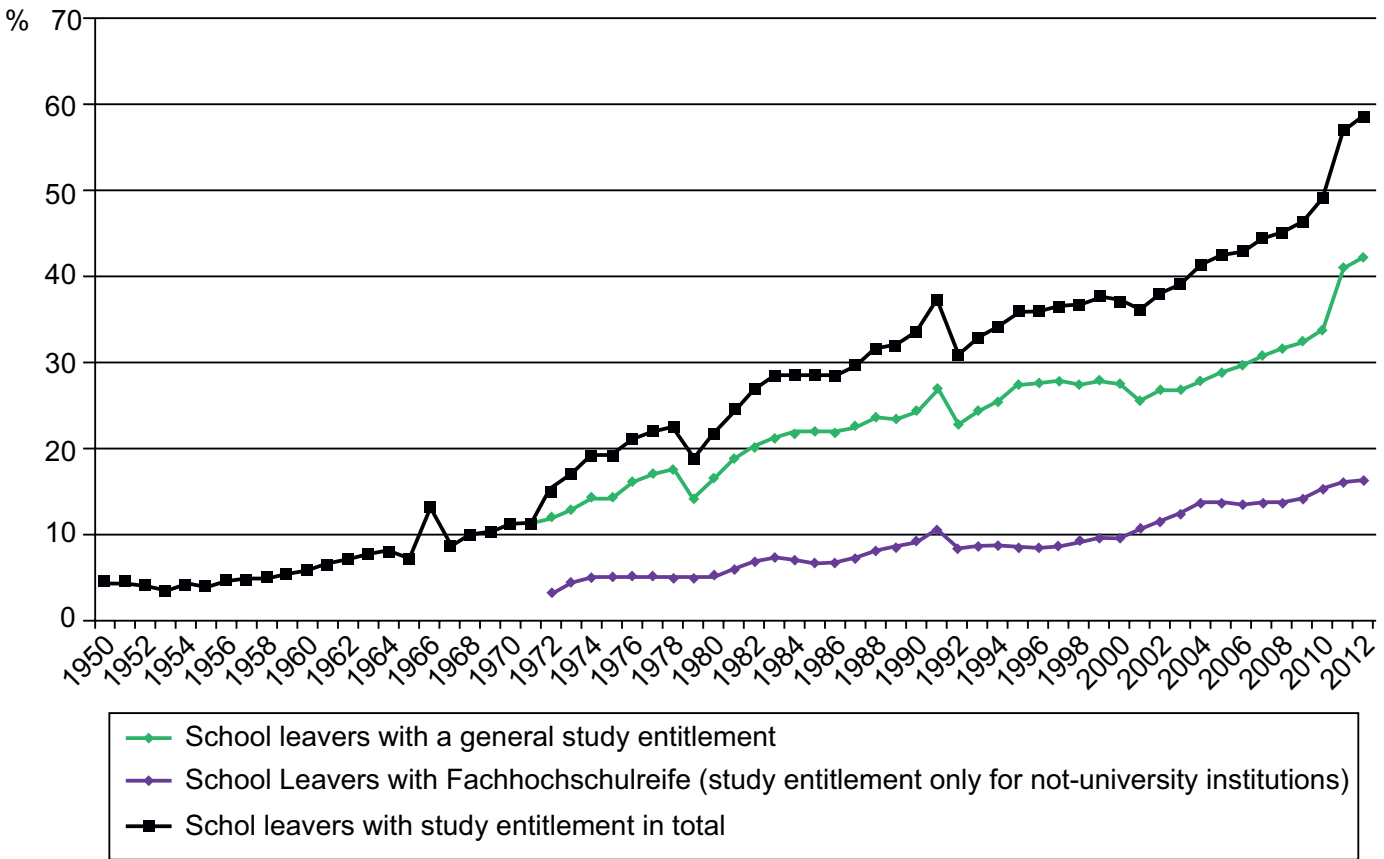

tion has grown massively whereas the traditional potential demand for VET has shrunk.

The decisive dynamic behind this shift in the educational choices and the allocation processes between alternative school types seems to be the increasing level of educational awareness, aspirations and ambitions in wider parts of the population. Obviously, educational decisions and choices have become more and more a selection between different options concerning later life chances: opening or limiting later qualification opportunities, the chances on the labour market, in employment and, lastly, during the life course. However, processes of opening up institutional transitions (e.g. between primary and grammar schools or between the lower secondary level and the upper level of grammar schools) have additionally reinforced the expansion.

The strict segmentation between VET and higher education (see part 2) and the close linkage between school certificates, further qualification paths, labour market and employment prospects and future life chances supports and confirms this social perception. The other side of this mechanism is the widespread feeling that VET means rather greater risks (e.g. higher unemployment or lower income) and fewer opportunities during the life course. And, in the past, most labour market and employment indicators have not contradicted or negated this estimation (Autorengruppe Bildungsberichterstattung 2014, p. 204, 339; Reinberg and Hummel 2007; Schmillen and Stüber 2014; Baethge et al. 2014 , p. 23 ff.). Hence, the actual polarisation of opportunities between the different status groups promotes the upward drift in the educational aspirations as a kind of social distinction. Different theoretical approaches and concepts - such as the rational choice theory, the human capital perspective, the theory of the social distribution function of education or the concept of meritocracy suggest or support this explanation (Wolter 2014).

\subsection{Changes in the labour market and employment}

In the dual system two issues need to be explained: First, the long-term decrease and the short-term stagnation of the supply for training places. Second, the inability of corporatist governance to supply training places according to demand and to solve the problems of transition from general education to vocational education in the past decade. To avoid explaining both issues by categories of actions taken by management and/or trade unions - which is often done in the daily policy debates - one needs to focus on the structural socioeconomic conditions underlying the actions of both firms and corporatist representatives.

Two separate structural developments might explain why the VET system has been faced with the problems outlined above. The first concerns the sectoral structural change towards a service economy (tertiarisation) and the corresponding tendency towards higher levels of cognitive skills required for employment. The second refers to the micro level of firms and the changing structures of management and labour organization corresponding to increasing global competition.

\subsubsection{From an industrial economy to a service economy}

Processes of rationalization in industry and structural change towards a service economy fundamentally affected the dual system of VET. Industrial production in the old 
Fig. 5 Employees and apprentices by production and service sector, 1990-2012 (old Länder). (Source: Employment survey of the Federal Employment Agency, as at due date per 31.12.; calculation of the Federal Institute for Vocational Education and Training (BIBB))

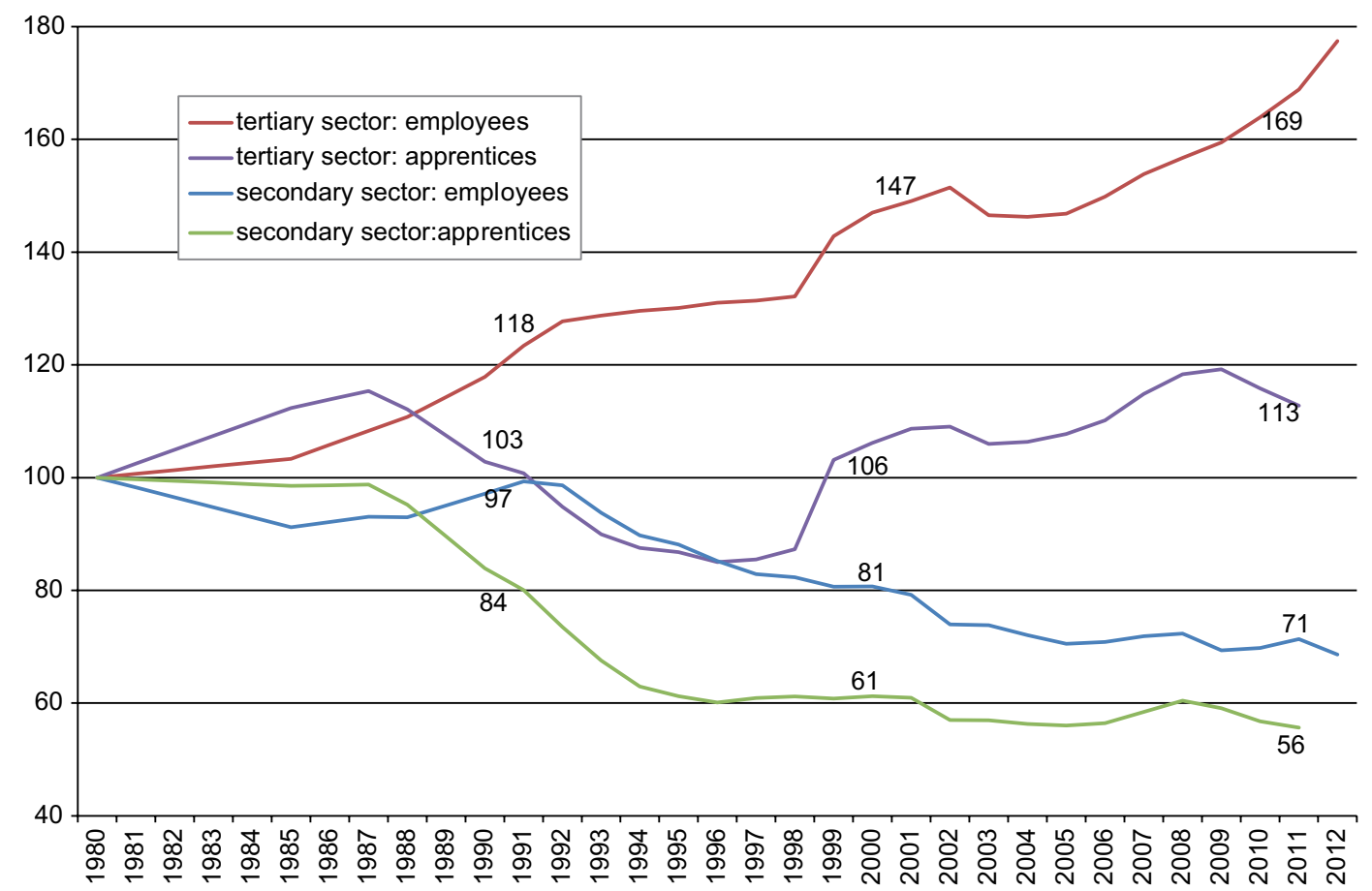

Länder has lost one third of its workers and about $45 \%$ of its apprentices since 1980 (Fig. 5). This explains why the vocational education of skilled workers in industrial production decreased so strongly.

Figure 5 shows the dramatic dynamics of sectoral structural change and their implications for VET. The declining number of employees in the production industries and the corresponding decrease in apprenticeships for skilled workers would not be a problem for VET if losses of employment and training places were replaced by the service sector. But this is not the case. Figure 5 shows that the declining number of employees in industry coincides with an even larger reduction of apprentices. In addition, an expansion of employment in the service sector corresponds with a clearly lower increase in apprentices.

With the structural change of employment towards a service economy, a sector with weaker increases in dual VET than in employment becomes dominant (Fig. 5). Up to now, it has not been possible to close this gap. Rather, it has expanded recently, indicating that qualification and recruitment strategies in many service sectors are more focused on the link between highly skilled (university and university of applied science degree) and low skilled workers than on dual vocational education and training forms (Schmidt 2010, p. 542).

The development towards a knowledge based and service economy goes hand in hand with far reaching changes in employees' professional profiles and vocational competences. Even taking into account the huge heterogeneity of skilled labour, one can say that the main line in the development of qualification requirements aims at reduc- ing craftsmanship and enhancing knowledge-based skills. The findings of empirical research on work organisation and qualification requirements of skilled work in the last 3 decades in Germany can be summarized as follows: The job profiles of skilled workers (Facharbeiter, -angestellte) are becoming more and more complex. Individual workers and work teams receive greater responsibility and more autonomy for their work organisation by decentralisation and the establishment of flat hierarchies within firms ${ }^{6}$ (Kuhlmann 2013; Kuhlmann and Schumann 2010). Though work experience unquestionably will remain a part of the competence profile, cognitive competences constitute the major share: e.g. analytical and problem-solving competences as well as critical thinking, organizational skills and the ability to communicate and cooperate with people from different departments, disciplines and even foreign countries. Recent studies on new forms of digitalised work (smart factories, Industrie 4.0 in Germany) confirm the trend towards highly cognitive skills in the field of industrial production work (Hirsch-Kreinsen 2014, p. 23 f.). Due to the unbroken upskilling trend, firms have changed their VET-programmes (i.e. dual studies) and patterns of recruitment (hiring more graduates from universities and universities for applied studies).

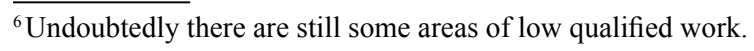




\subsubsection{The shift of management structures and work organisation}

The 1990s were characterised by the implementation of new forms of organisational regulation in the firms, which could be described with keywords such as the "introduction of market principles within organizations", "new cost management" and "global sourcing". On the one hand, this has resulted in the break-up of organizational structures according to the principle of departments in multifunctional units (decentralisation). On the other hand, it has led to increased account controlling of all operational sequences (Baethge and Baethge-Kinsky 1998; Kuhlmann 2009; Schumann et al. 1994).

As a consequence of the changed market conditions, demanding faster innovations and more flexible responses to customers' inquiries in firms, a new type of work organisation has been established. The former work organisation of close linkages between professions (Berufe) and functions has been replaced more and more by "process-oriented" arrangements of work. Traditional structures in firms and departments have been questioned and to some extent abandoned. The same applies to patterns of labour division and employees' posts within organisations (Baethge-Kinsky et al. 2006; Kuhlmann 2009; Kuhlmann and Schumann 2010). Company and work organisation according to business processes are more flexible and mobile than traditional organisational and operational structures. Here, the boundaries between low skilled, skilled and highly skilled workers become blurred. Occupational profiles requiring strictly defined task descriptions can easily constrain organisational processes. The German concept of Beruf has lost its binding character for work organisation in companies and new qualification profiles and combinations have emerged. As a consequence, the strategies for recruitment, education and further education, in particular in middle-sized and large companies, have changed.

From the perspective of the new organizational structures, focused on effectiveness and controlling, apprenticeships almost exclusively have appeared as cost factor (Baethge et. al. 2007, p. 28). Due to its long-term binding character, they have been considered risky investments for the future. In times of fundamental technological change their stabilising value for skill intensive production systems has appeared to be less important.

With some reservations, increased orientation towards demand and strict cost controlling could also be identified in observable long-term trends towards lowering the proportion of training places and apprentices (in this case, only a longitudinal comparison is meaningful) in the old Länder. Between 1985 and 2005 the percentage of firms offering training places declined from 34.4 to $22.6 \%$ (number of firms offering training per 100 companies) and the percentage of apprentices (number of apprentices per 100 employees) declined from 8.8 to $5.3 \%$. Since 1999 both percentages have decreased again by $10 \%$ (Autorengruppe Bildungsberichterstattung 2014, p. 276).

\section{New patterns of permeability and linkage between vocational and higher education in Germany}

Apart from the quantitative predominance of VET, the low level of permeability between VET and higher education was the second characteristic feature of the traditional German qualification model-deeply embedded in the traditional institutional order of post-school qualification provisions, in particular in the institutional regulation of access to higher education. Even if some significant changes could be observed; this new development has not eliminated the historical segmentation between vocational training and academic education. It has, however, reduced the strict segmentation of both sectors a little, showing that there is a new dynamic in the area in-between, beyond the traditional logic of segmentation (Wissenschaftsrat 2014).

A first indicator for a wider intermediate zone between VET and higher education is the frequent transition of school-leavers with the right to follow a study entitlement to vocational training. The VET system has profited from educational expansion to the extent that some students with the certificate for higher education decided to enter vocational education and training. In 1990 about one third of all school leavers with a higher education study entitlement belonged to this group. Most of them pursued dual VET and only a few of them entered school-based VET. This influx was reduced at the beginning of the year 2000 to about one quarter (Fig. 6). Some of them still transferred into higher education after completing VET.

Complementary to the shift in social demand for professional training from vocational to higher education, a new intersection or hybrid sector between both fields has evolved during recent years. The basic ideas behind this development is the implementation of new study models to combine or parallelise vocational training (or work) and studying. Three approaches are worth mentioning here: opening up access to higher education for non-traditional students, the establishment of procedures to recognise vocationally acquired competencies and the considerable extension of dual studies.

During the last 5-10 years there has been a new policy concern with regard to the establishment of regulations to open up higher education for highly qualified persons with a vocational qualification but without a school certificate, which entitles them to take up academic studies. Often, these students are called non-traditional students (NTS) (Slowey and Schuetze 2012; Wolter 2012). This is exactly a route to 
Fig. 6 Gross rate for vocational education from 1990 to 2012 (percentage of students with permission to enter university 6 months after leaving school). (Source: HIS-Studienberechtigtenbefragung)

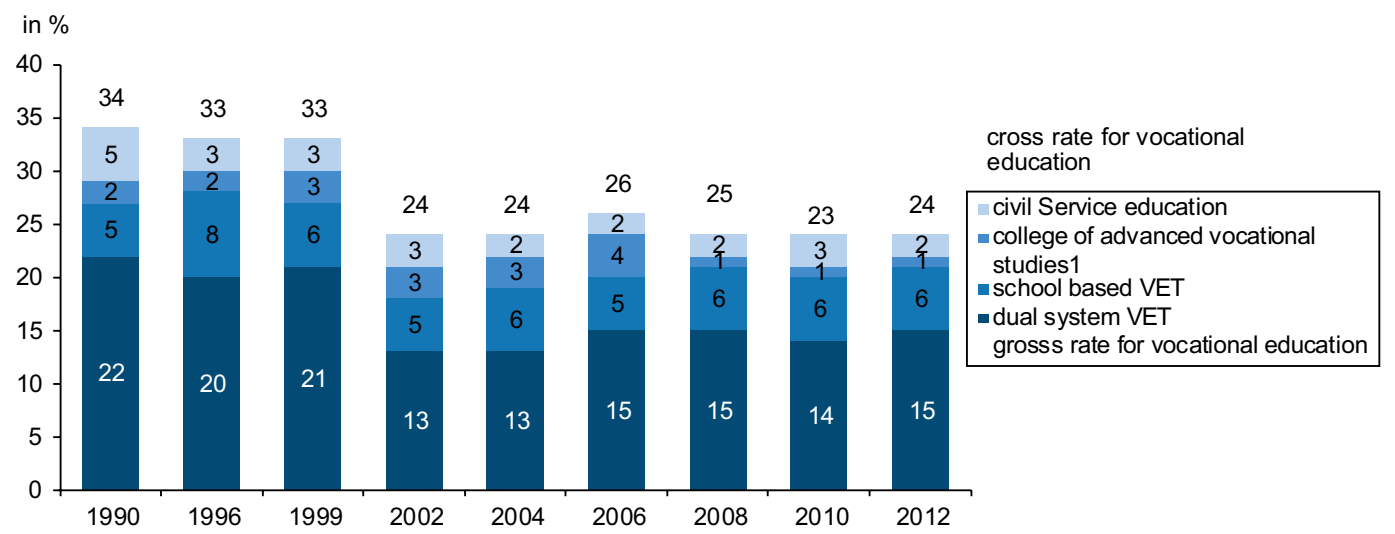

1) since 2008 without the former college of advanced studies Baden-Württemberg.

2) full time (basic) vocational school, specialized technical school, vocational schools for nursing).
Fig. 7 Proportion of non-traditional first-year students (\%), 2000-2012. (Source: Bildungsbericht 2014, p. 126 f.) (The narrow and the wider definition refer to the registration in the official higher education statistics. The wider definition includes the group of non-traditional students with a further education degree (e.g. as an industrial or craftsman master)

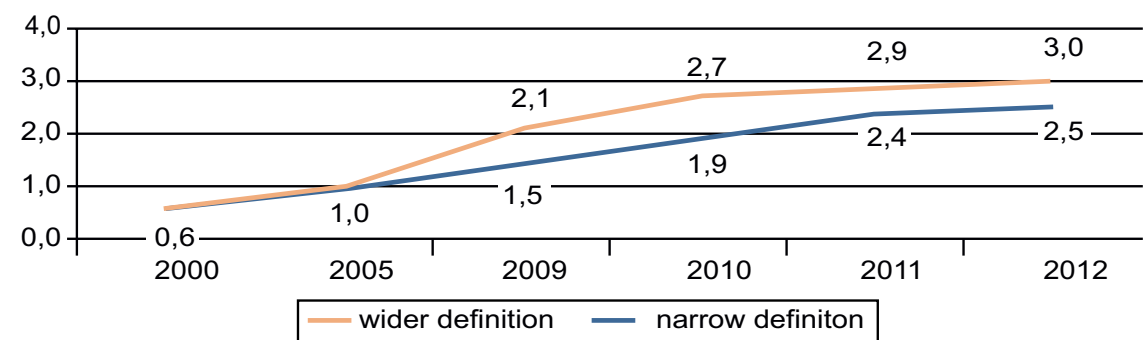

higher education that is not consistent with the tradition of segmentation. During the last years there have been several measures at federal or state level to widen access for new target groups with a vocational or further education background (Dahm et al. 2013; Wolter et al. 2014).

According to the available data, non-traditional access routes have not reached great importance so far. However, a small increase has been observed. About $90 \%$ of all new entrants to the university sector had the general qualification entitling them to admission, the Abitur. Only $2 \%$ of all new entrants in universities came via the non-traditional route in a strict sense. In sector Fachhochschulen sector their proportion is a little higher but also not really large. In both sectors together not more than about $3 \%$ of first-year students are non-traditional (Fig. 7). The proportion varies between Länder, between institutions and also between subjects. So it is fair to say that the structure of access in German higher education is still very Abitur-centred, and non-traditional access routes have played only a very marginal but increasing role up to now.

The main reason for the still small share of non-traditional students in German higher education includes the lack of flexibility in the organisation of studies and the delivery modes and the lack of flexible admission procedures (including recognition of prior learning). Therefore, some programmes have recently been developed and implemented to promote the establishment of recognition procedures and more flexible delivery modes of courses.

The issue of recognition is prominent on the agenda of the Bologna process, the parallel Copenhagen process and the implementation of a European Qualifications Framework (EQF) for Lifelong Learning. Higher education institutions should recognise prior learning outcomes to be equivalent to certain study requirements after a formal procedure of evaluation. This idea introduces a mechanism of opening and permeability into highly regulated authorisation systems such as the German one based primarily on formal qualifications that include the entitlement to study at a university. This idea seems to be diametrically opposed to the tradition of segmentation between vocational and higher education. In the meantime, many higher education institutions - more in the sector of Fachhochschulen than universities-have implemented such procedures of recognition, even though the situation is still far away from being introduced on a country- or institutional-wide basis.

Furthermore, the number of study provisions combining vocational training or work on the one hand and studying on the other hand, sometimes called hybrid studies (Graf 2013), has increased considerably during the last years - and also the number of students enrolled in such programmes 
(Wolter et al. 2014). In the area of initial higher education the most dynamic kind of provision refers to so-called dual studies, combining academic studies with practical training at the work-place, sometimes leading to two degrees (a Bachelor and a VET diploma), sometimes only to an academic degree. The majority of such courses is offered in the Fachhochschulen sector

Of course, this training segment of dual studies represents only a very small, though increasing share in the complete provision in German higher education. However, the extension of such hybrid studies signalises a growing interest in the institutionalisation of provisions beyond the traditional distinction between vocational training and higher education.

\section{Conclusions}

Recent developments in VET and higher education in Germany show that in the past decades there was a shift in the relative proportions in both sectors within the German education system towards higher education. Moreover, fundamental changes took place in both sectors, while at the same time remaining largely institutionally separated with little permeability between both sectors: In higher education this refers to rapid changes due to study reforms (Bologna process) and institutional differentiations of study programmes (universities of applied sciences (Fachhochschule)), cooperative university programmes (Duale Hochschule), and others. In VET this relates to the strong social structuring of occupations according to the level of previous general education, unresolved problems of transition to VET for children of the lower classes, in particular migrants, and the decreasing ability of the VET system to supply training places according to demand. As a result, almost one-fifth of the population aged 30-35 currently enters the labour market without a formal qualification (Autorengruppe 2012, p. 43).

These developments will have major impacts on the labour market and social structure. The landscape of occupations will become more confusing in both educational systems, in particular in higher education. Moreover, the adjustment processes of supply and demand will become more difficult. The large expansion of the number of university students in the last decades is a result of individual educational interest rather than economic demand - contrary to the developments in the dual VET system. In addition, such problems of matching between supply and demand in the labour market go hand in hand with more difficult coordination between the qualification requirements of the economy and the curricula in higher education. Up to now universities have not succeeded in implementing labour market oriented BA study programmes required by the Bologna
Process. Therefore, similar problems of matching between labour market requirements and higher education cannot be excluded in the medium term.

The integration of young adults into the labour market, which was up to now the main strength of the German educational system (also in times of crises), will be more difficult and individualised. Due to the increasing importance of higher education qualifications, the percentage of takeover agreements secured by labour contracts with respect to the total number of new employees is declining: the higher the number of university graduates the more problematic their transition to and further career success on the labour market could become.

Above all, one can expect that the integration of low qualified people into vocational education and the labour market will become even more precarious than in the past. In the past decade corporate governance did not even succeed in ensuring training places for even half of the young people with a maximum secondary school leaving certificate (Hauptschule) after leaving school. A lack of education implies an increased labour market risk: The unemployment rate of young people who do not graduate is more than twice as high as of young people who do.

Finally, in view of the political economy of skill formation one can assert that, in the past, the German model of VET represented occupational and social integration of the working class by education. This was successful for vocational education at a medium skill level for a long time, but only to a very limited extent for access to higher education and social advancement. The concept of social integration might be successful for larger numbers of young people in the future. However, there are no indications that occupational integration of educationally disadvantaged young people will be more successful in the future than in the first decade of the twenty-first century.

Another social effect should not be ignored: Up to now in Germany, VET has represented not only a mode of qualification but also a mode of socialisation (Heinz 1995; Daheim 2001). This mode of socialization within company-based training mainly contributed to the potential of solidarity within and outside of the trade unions and therefore represents an important basis for the German welfare state. Compared to company-based and work-related education, higher education is strongly individualised. The shift towards higher education could lead to a reduction of the potential for solidarity in society. The social background of students might strengthen this tendency.

In conclusion, we return to the question of political governance. The corporatist governance of the dual VET system, as an important pillar of the German production and social model, is more and more under pressure, for at least three reasons: 
- The more VET shifts towards higher education, the smaller the scope for steering by the corporatist governance model. The steering of the higher education system is regulated by the Länder and the autonomy of academic institutions (universities). Considering the tradition of universities and academic freedom as guaranteed by the German constitution (GG $\S 5$ ) it is hard to imagine that corporatist governance of higher education will become reality. Moreover, by the shift of educational financing from private companies to the Länder (higher education) the importance of the state in steering rises.

- The weaknesses of corporatist governance in VET, which became evident during the past decade, demanded political legitimation. This refers in particular to its inability to provide training places tailored to the market needs and to provide training places to low qualified school-leavers.

- Against the background of knowledge development, the problems of educationally disadvantaged young people on the one hand and better access of apprentices to higher education on the other hand may not be solved on the basis of traditional options through negotiation among the social partners but rather by implementing more instruments of education policy. The competences of the social partners in this field seems to be on the weak side.

The corporatist governance of VET will become less important in the German educational system as a whole. Also, for the remaining sector of dual VET, new perspectives are needed to ensure young people of equal participation in education and at the same time to secure the importance of the social partners in educational policy.

\section{Kurzfassung}

Das deutsche Ausbildungssystem, insbesondere das duale System der Berufsausbildung, wird in der politischen Ökonomie aus wenigstens zwei Gründen als Grundpfeiler des deutschen Modells angesehen: Zum einen ist die Facharbeiterausbildung unauflöslich mit dem deutschen Industrialisierungspfad der diversifizierten Qualitätsproduktion verbunden, gleichsam als dessen qualifikatorisches Rückgrat. Zum anderen stellt das duale Berufsausbildungssystem eines der wichtigsten Felder des deutschen korporatistischen Steuerungssystems dar.

Das deutsche Qualifizierungssystem als ganzes, d.h. sowohl die Fachkräfteausbildung unterhalb der Hochschulebene als auch die Akademikerausbildung, unterliegt einem folgenschweren strukturellen Wandel, bei dem sich der Schwerpunkt mehr und mehr in Richtung auf Hochschulbildung verschiebt, während das traditionelle duale System und die mit ihm verbundene korporatistische Governance sukzessive an Bedeutung verlieren. Dabei wird weniger die korporatistische Governance als institutionelle Form als vielmehr ihre politische Wirksamkeit und Reichweite im Qualifizierungssystem als ganzem in Frage gestellt. Denn akademische Bildung unterliegt einem anderen, stärker staatlich verfassten Steuerungsregime. Damit büßt das korporatitische Governance-Modell in Deutschland an Gewicht ein, ohne dass der traditionelle Industrialisierungspfad der Qualitätsproduktion verlassen werden muss. Wie neue politische und soziale Kohäsionsformen aussehen könnten und welche Rolle in ihnen noch korporatistische Institutionen spielen, lässt der Artikel am Ende ebenso bewusst offen wie die Frage, ob mit der beschriebenen Entwicklung das deutsche Modell im Kern getroffen wird. Die Fragen sind gestellt. $\mathrm{Zu}$ ihrer Beantwortung bedarf es weiterer Forschung und theoretischer Debatten.

Bei der Begründung der These spüren die Autoren in einem historisch langen Bogen den institutionellen Zusammenhängen zwischen Berufsausbildung, Hochschulbildung und Beschäftigungs- und Bildungsentwicklung nach. Die bereits in vorindustrieller Zeit angelegte Institutionalisierung der beiden heutigen Hauptbereiche der Berufsausbildung, duales System und Hochschulausbildung, vollzog sich im 19. und über weite Zeiträume im 20. Jahrhundert separiert voneinander und in unterschiedlicher Nähe zur industriellen Entwicklung: Während das System höherer Bildung (Gymnasial- und Universitätsausbildung) lange Zeit fernab von der, zum Teil sogar im Gegensatz zur Industrialisierung stand, wurde das Berufsbildungssystem weitgehend in den Industrialisierungsprozess inkorporiert.

Dieses bis heute nachwirkende „deutsche BildungsSchisma“" (Baethge) bedeutet, dass beide Bereiche unterschiedlichen institutionellen Ordnungen und Steuerungsprinzipien sowie unterschiedlichen Entwicklungsdynamiken folgen: In der inhaltlichen Gestaltung blieb die duale Berufsausbildung relativ eng an die qualifikatorischen Erfordernisse von betrieblicher Arbeit und beruflich organisierten Arbeitsmärkten gebunden, während die Hochschulausbildung sich primär an der Entwicklung der Wissenschaften orientierte. In der politischen Steuerung konnte die Berufsausbildung nach einem Jahrzehnte langen Kampf der Gewerkschaften im Berufsbildungsgesetz von 1969 in den Nachkriegskorporatismus der Bundesrepublik einbezogen werden, während höhere Bildung und Hochschulstudium staatlich reguliert bleiben.

Die beiden institutionell gegeneinander separierten Ausbildungssektoren konnten bis zum Ende des 20. Jahrhunderts mehr oder weniger berührungsfrei nebeneinander existieren, ohne dass es zu gravierenden qualifikatorischen Engpässen in der deutschen Wirtschaft oder auch zu größeren sozialen Konflikten gekommen wäre. Konflikte entzündeten sich auch nicht daran, dass ein beträchtlicher Teil der Bildungsungleichheit in Deutschland auf die mangelhafte Durchlässigkeit vom Berufsbildungs- ins Hochschulsystem 
zurückzuführen ist. Den Grund für beide Sachverhalte kann man in dem spezifischen deutschen Industrialisierungsbzw. wirtschaftlichem Entwicklungspfad sehen: Qualifikatorisch basiert er bis ins letzte Viertel des 20. Jahrhunderts auf einem breiten Fundament beruflich ausgebildeter Fachkräfte, einem kleinen Prozentsatz akademischer Experten und einem im Vergleich mit anderen westlichen Gesellschaften wie Frankreich, USA und Großbritannien kleinem Anteil Geringqualifizierter. Das breite Fachkräftefundament bildete einen mittleren Block in der Sozialstruktur, der, selbst auf die duale Ausbildung vereidigt, mehr soziale Bildungsgleichheit nicht politisch offensiv einklagte.

Erst im ersten Jahrzehnt des neuen Jahrhunderts kam es zu einem Umbruch in der deutschen Berufsbildungsgeschichte, der sich aber latent bereits seit längerem angebahnt hatte und jetzt Mängel des dualen Berufsausbildungssystems unabweisbar zu Tage treten lässt. Seinen spektakulären Ausdruck fand dieser Umbruch darin, dass seit 2011 die jährlichen Studienanfängerzahlen in etwa gleich hoch sind wie die Neuzugänge zur dualen Ausbildung und dieser Angleichung eine langfristige gegenläufige Entwicklung beider Sektoren zugrunde liegt: einen kontinuierlichen Anstieg der Studienberechtigtenquote auf über 50\% einer Kohorte korrespondiert ein Rückgang der Ausbildungsneuzugänge um über $15 \%$ seit der Jahrhundertwende. Verbunden ist diese Entwicklung in der Berufsausbildung damit, dass seit über einem Jahrzehnt das Ausbildungsplatzangebot im Aggregat immer deutlich hinter der Nachfrage zurückgeblieben ist, und zeitweise bis zu $40 \%$ der ausbildungsinteressierten Jugendlichen zunächst in irgendwelche Übergangsmaßnahmen abgedrängt wurden - unter ihnen vor allem solche mit maximal Hauptschulabschluss und häufig mit Migrationshintergrund.

Die Ursachen für diesen Umbruch sehen die Autoren in langfristig wirksamen strukturellen Entwicklungen, die politisch nur begrenzt beeinflussbar sind: Zum einen in der seit den Bildungsreformen der 1960er/1970er Jahre starken Expansion des Zugangs zu höherer und Hochschulbildung; zum anderen in dem sektoralen Strukturwandel zu einer wissensbasierten Ökonomie, in der Dienstleistungsbeschäftigung dominant geworden ist. Die dem Strukturwandel inhärenten Berufs- und Tätigkeitsprofile beruhen zunehmend (schlagwortartig gesprochen) auf theoretischen Problemlöse-, Selbstorganisations- und sozial-kommunikativen Kompetenzen. Diese allgemeine upskilling-Tendenz eröffnet zum einen Hochschulabsolventen bessere Berufschancen und kann zum anderen schulisch gering qualifizierten Jugendlichen den Zugang zur Ausbildung versperren.

Es spricht vieles dafür, dass bereits auf mittlere Sicht der Hochschulsektor der strukturbestimmende Bereich des gesamten Qualifizierungssystems wird. In welcher Form dies geschieht - z.B. mit einem höheren Anteil dualer Studiengänge - und ob die Hochschulen genügend praxisbezo- gene Studiengänge anzubieten in der Lage sein werden, muss vorerst offen bleiben. Die Frage aber wird kaum im Rahmen korporatistischer Aushandlungsprozesse beantwortet werden, weil die Hochschulen nicht auf ihre verfassungsmäßigen Garantien für die Freiheit von Forschung und Lehre verzichten werden. Angesichts der in der aktuellen Umbruchsituation zu erwartenden Unsicherheiten bei der Bereitstellung von Ausbildungsangeboten sind auch Engpässe in der Qualifikationsversorgung der Wirtschaft nicht auszuschließen.

In ihrer kurzen Lebenszeit von knapp 50 Jahren hat die korporatistische Governance viel für die Modernisierung der dualen Ausbildung in der Entwicklung von Berufsbildern und betrieblicher Ausbildungsgestaltung erreicht. Die Erfolge blieben aber eng auf die Ausbildungsgestaltung bezogen, sie haben weder die Durchlässigkeit zum Hochschulstudium nachhaltig verbessert noch ein hinreichendes Ausbildungsangebot sicherstellen können. In beiden Punkten ist die politische Legitimationskraft des Korporatismus eher schwach geblieben und gesunken.

Die Autoren verweisen auf ein weiteres mit dem Umbruch im Berufsbildungssystem verbundenes Problem für das deutsche Modell: Die duale Berufsausbildung war nicht nur ein Qualifizierungs-, sondern mit seiner Inkorporation in den betrieblichen Arbeitsprozess immer auch ein Sozialisationsmodell, das innerhalb und außerhalb der Gewerkschaften ein wichtiges Solidaritätspotential schuf. Eine Gewichtsverlagerung zur Hochschulausbildung würde diese Solidaritätsressourcen strukturell verringern, da akademische Bildung traditionell stark individualisiert ist, entfernt von betrieblichen Arbeitsprozessen abläuft und nur geringe kollektive Solidaritätsanreize enthält.

\section{References}

Abelshauser, W.: Deutsche Wirtschaftsgeschichte seit 1945. München (2004)

Andres, L., Pechar, H.: Participation patterns in higher education: A comparative welfare and production régime perspective. Eur. J. Educ. 48, 247-261 (2013)

Autorengruppe Bildungsberichterstattung, Bildung in Deutschland, und div. Jahrgänge (2012)

Baethge, M.: Das deutsche Bildungs-Schisma. In: Lemmermöhle, D., Hasselhorn, M. (eds.) Bildung-Lernen, pp. 93-116. Göttingen (2007)

Baethge, M.: Die schleichende Erosion im governance Modell des deutschen Berufsbildungssystems. In: Dingeldey, L., Holtrup, A., Warsewa, G. (eds.) Wandel der Goverance der Erwerbsarbeit, pp. 273-300. Wiesbaden (2014)

Baethge, M., Baethge-Kinsky, V.: Jenseits von Beruf und Beruflichkeit. Mitteilungen aus der Arbeitsmarkt- und Berufsforschung (1998)

Baethge, M., Wieck, M.: Soziale Selektion (Öffnungs- und Schließungstendenzen) in der beruflichen Ausbildung. MS, Göttingen (2013)

Baethge, M., Solga, H., Wieck, M.: Berufsbildung im Umbruch. Signale eines überfälligen Aufbruchs. Berlin (2007) 
Baethge, M., Kerst, C., Leszcensky, M., Wieck, M.: Zur neuen Konstellation zwischen Hochschulbildung und Berufsausbildung. Hannover (Forum Hochschule 3 (2014), (2014)

Baethge-Kinsky, V., Holm, R., Tullius, K.: Dynamische Zeitenlangsamer Wandel: Betriebliche Kompetenzentwicklungen von Fachkräften in zentralen Tätigkeitsfeldern der deutschen Wirtschaft. MS, Göttingen (2006)

Brennan, J.: Higher education and social change. High. Educ. 56, 381-393 (2008)

Busemeyer, M.R., Trampusch, C.: The Political Economy Of Collective Skill Formation. Oxford (2012)

Cortina, K.S., Baumert, J. et al. (eds.): Das Bildungswesen in der Bundesrepublik Deutschland. Hamburg (2008)

Culpepper, P., Finegold, D. (eds.): German skills machine: Sustaining comparative advantage in a global economy, policies and institutions: Germany, Europe and transatlantic relations. New York (1999)

Daheim, H.: Berufliche Arbeit imÜbergang von der Industrie- zur Dienstleistungsgesellschaft. In: Kurk, T. (ed.) Aspekte des Berufs in der Moderne, pp. 21-38. Opladen (2001)

Dahm, G., Kamm, C., Kerst, C., Otto, A., Wolter, A.: „Stille Revolution?" - Der Hochschulzugang für nicht-traditionelle Studierende im Umbruch. Die Deutsche Schule. 105(4), 382-401 (2013)

deWeert, E.: Contours of the emergent knowledge society: Theoretical debate and implications for higher education research. High. Educ. 38, 49-69 (1999)

Erikson, R., Goldthorpe, J.H.: The Constant Flux. Clarendon Press, Oxford (1992)

Gibbons, M., Limogenes, C., Nowotny, H., Schwartzman, S., Scott, P., Trow, M.: The New Production of Knowledge: The Dynamics of Sciences and Research in Contemporary Societies. London (1994)

Graf, L.: Applying the varieties of capitalism approach to higher education. Comparing the internationalization of German and British universities. Eur. J. Educ. 44(4), 569-585 (2009) (Special Issue: Networks in Education. Benefits and Issues in Europe)

Graf, L.: Internationalization Strategies in Higher Education Systems. A Variety of Capitalism Analytical Framework. In: Egbert, H., Esser, C. (eds.): Aspects in Varieties of Capitalism. Dynamics, Economic Crisis, New Players. INFER Series in Applied Economics, Vol. 3. Saarbrücken, p. 203-227 (2010)

Graf, L.: The Hybridization of Vocational Training and Higher Education in Austria, Germany and Switzerland. Budrich, Opladen (2013)

Greinert, W.-D.: Erwerbsqualifizierung jenseits des Industrialismus. $\mathrm{Zu}$ Geschichte und Reform des deutschen Systems der Berufsbildungspolitik. Frankfurt a. M. (2007)

Heinz, W.R.: Arbeit, Beruf und Lebenslauf, Weinheim, München (1995)

Hirsch-Kreinsen, H.: Wandel von Produktionsarbeit—,Industrie 4.0“. Technische Universität, Dortmund (2014) (Arbeitspapier Nr. 38)

Kuda, E., Strauß, J., Spöttl, G., Kassebaum, B. (Hrsg.): Akademisierung der Arbeitswelt? Hamburg (2012)

Kuhlmann, M.: Perspektiven der Arbeitspolitik nach der Krise: Entwicklungslinien und Handlungsbedingungen. WSI-Mitteilungen. 62(12), 675-682 (2009)

Kuhlmann, M.: Neue Produktionskonzepte/Innovative Arbeitspolitik. In: Hirsch-Kreinsen, H., Minssen, H.. (eds.), Lexikon der Arbeitsund Industriesoziologie, Berlin, p. 358-364 (2013)

Kuhlmann, M., Schumann, M.: Einschätzungen zum Forschungsstand im Bereich Arbeitsgestaltung. In: Metall, I.G. (ed.) Beiträge zur Arbeitspolitik und Arbeitsforschung. Handlungsfelder, Forschungsstände, Aufgaben, pp. 68-73. IG Metall, Frankfurt a. M. (2010)
Maaz, K., Baumert, J., Trautwein, U.: Genese sozialer Ungleichheit im Kontext der Schule: Wo entsteht und vergrößert sich soziale Ungleichheit? In: Krüger, H.-H., Rabe-Kleberg, U., Kramer, R.T., Budde, J. (Hrsg.): Bildungsungleichheit reviseted, Wiesbaden, S. 69-201 (2010)

Reinberg, A, Hummel, M.: Qualifikationsspezifische Arbeitslosigkeit im Jahr 2005 und die Einführung der Hartz-IV-Reform - empirische Befunde und methodische Probleme, Nürnberg, (IABForschungsbericht 09/2007) (2007)

Schmidt, N.: Auswirkungen des Strukturwandels der Wirtschaft auf den Bildungsstand der Bevölkerung. Wirtschaft und Statistik. 6, 537-551 (2010)

Schmillen, A., Stüber, H.: Bildung lohnt sich ein Leben lang. In: IABKurzberichte 1/2014 (2014)

Schumann, M., Baethge-Kinsky, V., Kuhlmann, M., Kurz, C., Neumann, U.: Trendreport Rationalisierung. Berlin (1994)

Slowey, M., Schuetze, H.G. (eds.): Global perspectives on higher education and lifelong learners. London (2012)

Soskice, D.: Divergent Production Regimes: Coordinated and Uncoordinated Market Economies in the 1980s and 1990s. In: Kitschelt, H., Lange, P., Marks, G., Stephens, J.D. (Hrsg.) Continuity and Change in Contemporary Capitalism, S. 101-134. Cambridge, UK (1999)

Statistisches Bundesamt: (Ed.) Bevölkerung und Erwerbstätigkeit. Stuttgart (Fachserie 1. Reihe 4.2.1) (2002)

Streeck, W.: On the Institutional Conditions of Diversified Quality Production. In: Matzner, E., Streeck, W.. (eds.), Beyoud Keynesianism, Aldershof, 21-61 (1991)

Thelen, K.: How Institutions Evolve. The Political Economy of Skills in Germany, Britain, the Unites States, and Japan. Cambridge University Press, Cambridge (2004)

Thelen, K.: Foreword. In: Busemeyer, M.R., Trampusch, Ch. (eds.): The Political Economy of Collective Skill Formation, Oxford University Press, p. V-XII (2012)

Thelen, K., Busemeyer, M.R.: Institutional Change in German Vocational Training: From Collectivism towards Segmentalism. In: Busemeyer, M.R., Trampusch, Ch. (eds.): The Political Economy of Collective Skill Formation. Oxford University Press. p. 88-100 (2012)

Välimaa, J., Hoffman, D.: Knowledge society discourse and higher education. High. Educ. 56, 265-285 (2008)

Wissenschaftsrat: (2013): Empfehlungen zur Entwicklung des dualen Studiums. Köln (WR)

Wissenschaftsrat: (2014): Empfehlungen zur Gestaltung des Verhältnisses von beruflicher und akademischer Bildung. Darmstadt

Wolter, A.: Germany: from individual talent to institutional permeability: changing policies for non-traditional access routes in German higher education, in: Slowey, M., Schuetze, H.G.. (eds.): Global Perspectives on Higher Education and Lifelong Learners. London, p. $43-59$ (2012)

Wolter, A.: Eigendynamik und Irreversibilität der Hochschulexpansion: Die Entwicklung der Beteiligung an Hochschulbildung in Deutschland. In: Banscherus, U., et al. (eds.): Übergänge im Spannungsfeld von Expansion und Exklusion. Bielefeld, p. 19-38 (2014)

Wolter, A., Kamm, C., Lenz, K., Renger, P., Spexard, A.: Potenziale des dualen Studiums in den MINT-Fächern - eine empirische Untersuchung. acatech STUDIE. München (2014) 
Martin Baethge, Dr., President of the Sociological Research Institute and Professor (em) at the University of Göttingen. 1973-2004 Professor for Sociology, faculty of social sciences University of Göttingen, 1975-2006 Director of the Sociological Research Institute (SOFI). Since 2005 Member of the consortium for the national educational report in Germany. Main fields of research: International comparative research on vocational education and training; large scale assessment in VET; social inequality in VET; transition from school to work; qualification development in the service sector; qualification and innovation.
Andrä Wolter, Dr., Professor for Higher Education Research at the Humboldt-Universität zu Berlin, Germany (since 2010). 1976-1990 academic assistant for empirical educational research at the University of Oldenburg. 1990-1993 head of the department for higher education at the Institut für Entwicklungsplanung und Strukturforschung, University of Hanover. 1993-2010 Professor for Policy Studies in Education, Dresden University of Technology. 2004-2006 head of the higher education research department of HIS Hochschul-Informations-System, Hanover. Member of the consortium for the national educational report in Germany. Main research fields: higher education policy, access to higher education, social and economic situation of students, social demand for higher education and participation in higher education, university continuing education and lifelong learning studies. 